\title{
The Central Great Lakes Geologic Mapping Coalition
}

The State Geological Surveys of Illinois, Indiana, Michigan, and Ohio joined with the U.S. Geological Survey (USGS, under the Earth Surface Dynamics Program) to form the Central Great Lakes Geologic Mapping Coalition. These four States have a similar geologic heritage and need to address common societal issues about land and water resources, the environment, and geologic hazards. By pooling their expertise and resources, the five Geological Surveys can address these issues more effectively than could any one survey.

\section{Why a Geologic Mapping Coalition?}

During the last 1.8 million years, glaciers repeatedly advanced and retreated across the region, leaving behind a thick, complex blanket of intermixed layers of mud, clay, silt, sand, and gravel (fig. 1). To support sustainable development, decisionmakers need knowledge of the glacial and related deposits - their characteristics, threedimensional distribution, and thickness. To provide this knowledge, the Coalition will prepare 3-D maps and derivative products that require drilling and geophysical surveys that are too expensive for any one agency. These new products will provide customers with information on the following:

- utilizing water and mineral resources

- siting new facilities

- protecting the environment

- reducing costs of geologic hazards

\section{What Will the Coalition Do?}

As resources become available, the Coalition will produce detailed, digital, 3-D surficial geologic maps and derivative products. The Coalition's plan is described in USGS Open-File Report 99-349 (R.C. Berg and others, 2000). The plan has prioritized study areas (fig. 2) on the basis of the needs of more than 500 city, county, State, Federal, and private map users who attended geologic mapping forums in Indianapolis, Ind., and Columbus, Ohio.

During the 3-year pilot phase, new mapping techniques will be devised, staff will be trained, drilling and geophysical data will be collected, proposed customer needs will be refined, and the first products will be prepared. A 14-year intensive phase will follow for production of the maps and the digital data base.

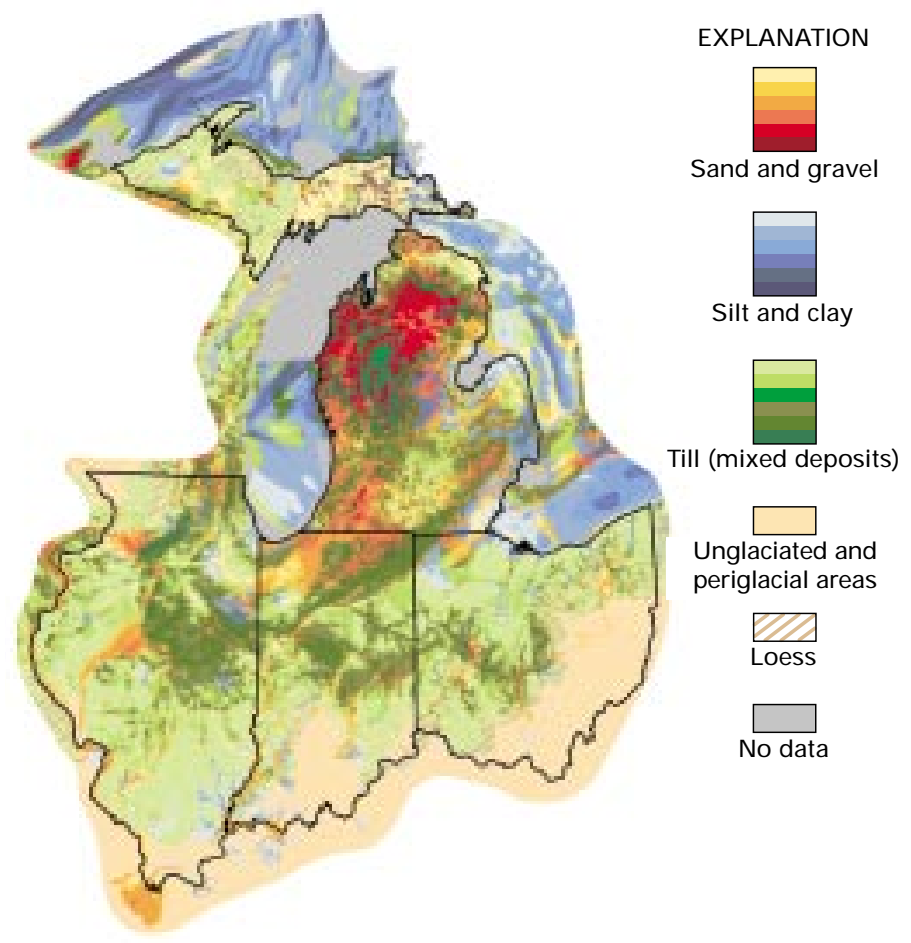

Figure 1. Glacial and related deposits of the Central Great Lakes States. Deeper colors are thicker deposits. From D.R. Soller, 1998, U.S. Geological Survey M iscellaneous Investigations Series M ap I-1970-B.

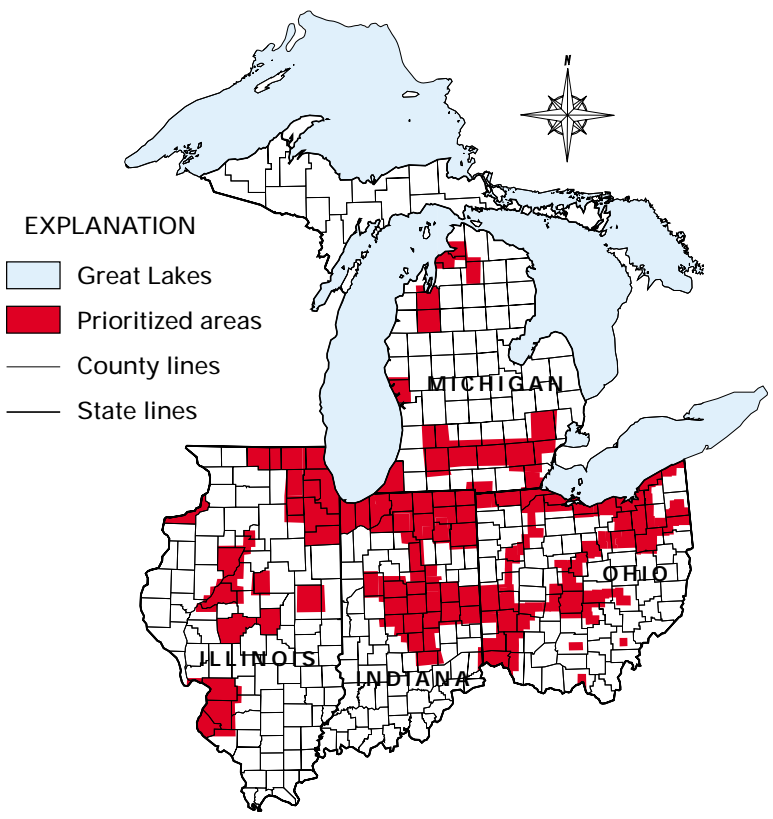

Figure 2. Proposed prioritized study areas. These areas were determined by customers. 


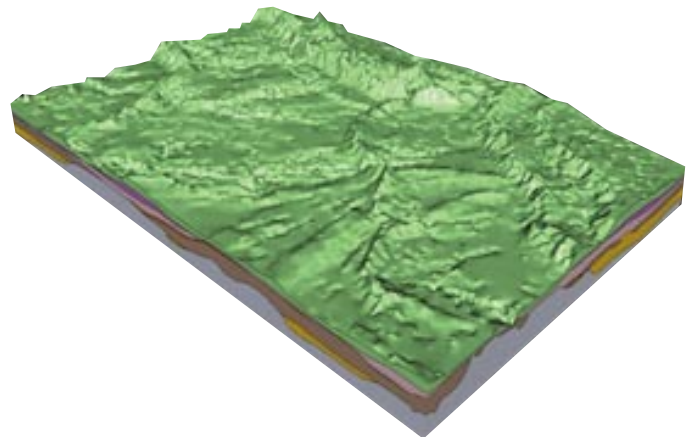

Figure 3. 3-D digital geologic map showing surface and subsurface layers and providing information on their characteristics. From D.R. Soller and others, 1999, U.S. Geological Survey Geologic Investigations Series M ap I- 2669.

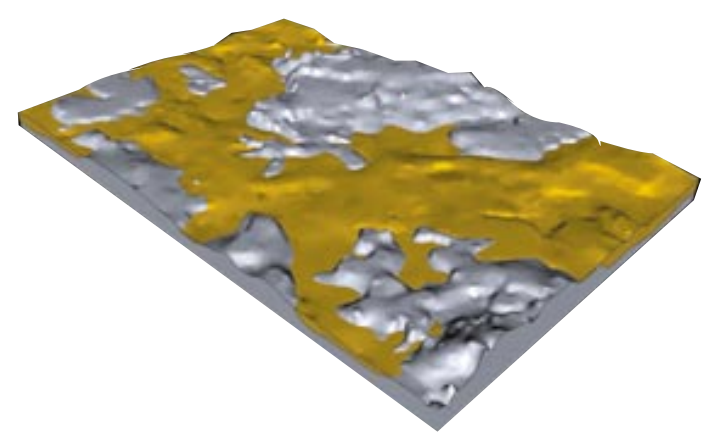

Figure 5. Derivative 3-D digital geologic map based on figure 3. It shows the bedrock surface (gray) and a top sand layer, an excellent ground-water source.

\section{What Will the Coalition Produce?}

- 3-D geologic maps (fig 3). More than 500 3-D geologic maps in digital format will be produced by the Coalition. To make these maps, subsurface data will be collected by advanced geophysical and drilling (fig. 4) techniques. The data will be stored in a digital data base that permits spatial analyses (with advanced computer geographic information systems) of ground-water and mineral resources, contaminant flow paths, and potential hazards.

- Derivative maps (fig. 5). The digital data base will be used to prepare derivative maps for specific customer needs. For example, the map in figure 5 enables hydrologists to visualize the shape of an aquifer and to manage and protect the ground-water resource.

\section{Who Will Use Coalition Products?}

- City, county, and State planners

- Water management agencies and utilities

- Public health and agricultural agencies

- County and State transportation departments

- State and Federal environmental protection agencies

- Builders, developers, and insurance companies

- Environmental and geological consultants

- Engineering firms and agencies

- The general public

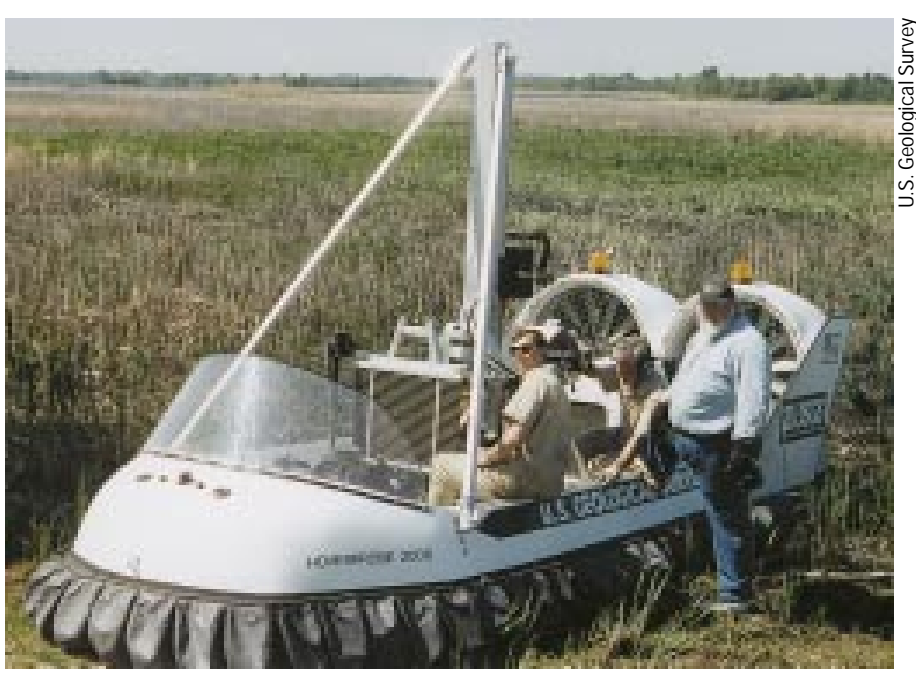

Figure 4. Hoverprobe drilling in an area not accessible by boats or trucks.

\section{What Will Be the Value of Coalition Maps?}

A geologic map is worth 25 to 39 times the cost of making the map, according to a new study by S.B. Bhagwat and V.C. Ipe (2000, Illinois State Geological Survey Special Report 3, Economic benefits of detailed geologic mapping to Kentucky). Coalition maps will be worth even more than traditional geologic maps because of the associated digital data bases and three-dimensional models of geology.

\section{What Will the Coalition Cost?}

- Pilot phase: $\$ 11$ million per year for 3 years

- Intensive phase: \$20 million per year for 14 years

\section{For additional information, please contact:}

Illinois State Geological Survey William Shilts, State Geologist 615 E. Peabody Drive Champaign, IL 61820-6964 (217) 333-5111

shilts@isgs.uiuc.edu

\section{Indiana Geological Survey}

John Steinmetz, State Geologist 611 N. Walnut Grove

Bloomington, IN 47405-2208

(812) 855-5067

jsteinm@indiana.edu

\section{Michigan Geological Survey} Division

Harold Fitch, State Geologist

735 E. Hazel St.

Lansing, MI 48909-7756

(517) 334-6907

fitchh@state.mi.us
Ohio Division of Geological Survey

Thomas Berg, State Geologist 4383 Fountain Sq. Dr. Columbus, OH 43224-1362 (614) 265-6988 thomas.berg@dnr.state.oh.us

\section{U.S. Geological Survey}

David Russ

Eastern Regional Geologist USGS, 953 National Center

Reston, VA 20192-0001

(703) 648-6660

druss@usgs.gov 